\title{
COMPARISON OF THE ADSORPTIVE PROPERTIES OF SOME ALBANIAN CLAYS TOWARD DIMETHOATE AND METHOMYL
}

\author{
Erinda Prifti $^{1 *}$, Nensi Isak ${ }^{1}$, Kledi Xhaxhiu ${ }^{1}$ \\ I*Department of Chemistry, Faculty of Natural Sciences, University of Tirana, Albania; \\ *Corresponding Author Erinda Prifti, e-mail: prifti.erinda@gmail.com;
}

Received January 2021; Accepted February 2021; Published March 2021;

DOI: https://doi.org/10.31407/ijees11.212

\begin{abstract}
This study evaluates and compares the adsorptive properties of four natural clays from Albania regions: Brari, Currila, Dardha and Prrenjasi, in regards to the adsorption of two insecticides, dimethoate and methomyl, from their aqueous solutions. Special studies on the adsorption of these two insecticides have been previously published by authors, [45], [58], [59], and [60] while this research is focused on the comparison of the adsorbent properties of the four above mentioned clays based on the obtained experimental results. Dimethoate adsorption was performed at $\mathrm{T}=25^{\circ} \mathrm{C}$, at concentrations of $0.200 \mathrm{~g} / \mathrm{L}, 0.300 \mathrm{~g} / \mathrm{L}, 0.400 \mathrm{~g} / \mathrm{L}$, and $0.500 \mathrm{~g} / \mathrm{L}$, for each type of clay and for methomyl, concentrations of $0.200 \mathrm{~g} / \mathrm{L}, 0.300 \mathrm{~g} / \mathrm{L}, 0.400 \mathrm{~g} / \mathrm{L}$, and $0.600 \mathrm{~g} / \mathrm{L}$, were analyzed at the same temperature. Adsorption time was extended for dimethoate from 6 hours to 144 hours, for 6 days, while for methomyl from 6 hours to 72 hours, for 3 days. The comparison of the experimental data obtained shows that natural clays are able to adsorb (depending on the concentration of the insecticide) from approximately $0.1 \mathrm{mg} / \mathrm{g}$ or $0.1 \mathrm{~g} / \mathrm{kg}$ technic dimethoate up to $0.8 \mathrm{~g} / \mathrm{kg}$, for the 48 -hour adsorption time, while for methomyl from $0.3 \mathrm{~g} / \mathrm{kg}$ to $1.4 \mathrm{~g} / \mathrm{kg}$. It is concluded that, since insecticides used in agriculture belong to rates of the order of $0.1 \mathrm{mg} / \mathrm{kg}$ soil, or $0.05-0.1 \mathrm{~g} / \mathrm{m}^{2}$, in their natural state, these clays can be successfully used for the treatment of contaminated groundwater with these insecticides. The clays of Dardha and Prrenjas show better adsorption properties toward methomyl, while those of Brari and Dardha show better adsorption properties toward dimethoate. This depends on the structure, physicochemical properties and the associated substances of each insecticide. In general, methomyl adsorption on these clays is better and faster than that of dimethoate. The optimal contact time of clay-methomyl in aqueous solution varies from 24 to $48 \mathrm{~h}$, further reduction of the adsorbed amount is observed due to the counter-desorption phenomenon. The adsorption of dimethoate is slower therefore the optimization of contact time clay-aqueous solution dimethoate extends to the interval of $120 \mathrm{~h}$. The adsorption capacities of the four clays studied reveal the possibility of their practical employment in groundwater purification from residues of dimethoate and methomyl, used in agriculture.
\end{abstract}

Keywords: evaluates, compares, adsorptive properties, natural clays, regions, Albania. 